\title{
Doktorgradens prøveforelesning har for snevert emnevalg
}

\author{
Emnet som oppgis til prøveforelesning for den medisinske doktorgraden, er viktig av flere grunner. \\ Det har utviklet seg en praksis som står i strid med formålet om at kandidaten skal vise faglig bredde. \\ Denne praksisen bør stoppe.
}

Den medisinske doktorgraden (doktor $=$ lærer) gir kompetanse til å undervise ved universiteter. Noe av denne lærerkompetansen går på kunnskaper og ferdigheter som forsker. Dette prøves gjennom vurderingen av avhandlingen og disputasen. Men noe av lærerkompetansen vurderes også gjennom kandidatens prøveforelesning. Her blir kandidatens pedagogiske ferdigheter vurdert. Etter tradisjonen har den oppgitte forelesningen også prøvd kandidaten i to andre ferdigheter: (a) evnen til å utarbeide en god studentforelesning på kort tid, og (b) evnen til å gjøre dette på et emne som ligger utenfor avhandlingens fagområde. Her skal altså kandidaten både vise evne til konsentrert arbeid og å kunne bevege seg i bredden faglig sett. Dette er ferdigheter som enhver universitetslærer trenger.

I de senere årene har man dessverre begynt å velge det oppgitte prøveforelesningstemaet tett opptil kandidatens avhandling. Dermed bortfaller kravet om å vise

\section{RAMME 1}

Eksempler - hentet fra universitetenes nettsider - på at prøveforelesningene ligger for tett opptil avhandlingene

- Universitetet i Tromsø. Disputas: Life style factors and risk of venous thromboembo-

lism. Forelesning: Prevention of recurrent venous thromboembolism.

- Universitetet i Bergen. Disputas: Safe and sound - The effect of ultrasound power on foetal measurements. Forelesning: Diagnosis, surveillance and timely delivery of early and late fetal growth restriction.

- Norges teknisk-naturvitenskapelige universitet. Disputas: Bronchial microdialysis. Forelesning: Nedsatt lungefunksjon hos kritisk syke pasienter - diagnose og behandling. Cytokiners rolle og fremtidsperspektiver.

- Universitetet i Oslo. Disputas: Children and adolescents with diabetes, - present state and future possibilities - A study of factors affecting competence and treatment results in children and adolescents with type I diabetes. Forelesning: Fysiologiske og psykologiske utviklingstrekk hos barn og ungdom med diabetes. evne til å orientere seg i bredden. Dette har skjedd uten at man offisielt er blitt enig om det, og uten at denne praksisendringen er nedfelt i reglement eller instruks for bedømmelseskomiteer. I reglementet for Norges teknisk-naturvitenskapelige universitet står det til og med svart på hvitt at hen-

\section{«l de senere årene har man dessverre begynt å velge det oppgitte prøveforelesningste- maet tett opptil kandi- datens avhandling»}

sikten med prøveforelesningen «er å prøve kandidatens evne til å tilegne seg kunnskaper utover avhandlingens tema og evnen til å formidle disse i en forelesningssituasjon» (1). Dette er en presis formulering av hvordan praksis fortsatt bør være ved alle fakulteter.

\section{Litt historikk}

Da jeg kom inn i akademisk medisin i 1960årene, holdt kandidaten to forelesninger: én med selvvalgt emne og én med oppgitt emne. Når det gjaldt selvvalgt emne, ble det forventet at doktoranden enten valgte et tema fra et annet prosjekt enn doktorgradsprosjektet som vedkommende hadde vært involvert i, eller valgte et tema som interesserte doktoranden utenom doktorgradstemaet. Ikke sjelden fungerte denne forelesningen som en kritisk litteraturgjennomgang før postdoktorprosjektet ble designet.

Med forelesningen over oppgitt emne skulle doktoranden både vise seg kompetent til på to uker å utarbeide en akademisk forelesning for langtkomne studenter, og gjøre det $i$ et tema som lå godt unna doktorgradstemaet. Det siste prinsippet var derfor at kandidaten skulle vise evne til å kunne undervise $\mathrm{i}$ andre temaer enn sitt spesialfelt. Handlet avhandlingen om hjertesykdom, kunne den oppgitte forelesningen være kritisk å vurdere diagnostiske metoder ved infeksjonssykdommer. Handlet avhand- lingen om angstlidelser, kunne den være å redegjøre for og vurdere ulike behandlingsformer for delirium tremens. Handlet avhandlingen om en biokjemisk problemstilling, kunne den oppgitte forelesningen være å redegjøre for nyere teorier om årsaksforhold til kreft i tykktarmen. Hadde avhandlingen et gjennomgående metodeproblem som var for stort til å bruke hele disputasen på, ga man doktoranden, som oppgitt emne, en mulighet til å vise at vedkommende kunne håndtere dette metodeproblemet adekvat, for eksempel ved en avhandling i radiologi: «Gi en kritisk vurdering av reliabilitet og validitet ved bedømmelse av røntgen thorax bilder.» I psykiatri kunne det hete: «Spørreskjemametoder for diagnostisering av depresjon, en kritisk vurdering.»

\section{Dagens situasjon}

Alle fakulteter har nå den ordningen at doktoranden gir en populærvitenskapelig fremstilling av avhandlingen på 20 minutter før selve disputasen. Den selvvalgte forelesningen er dermed fjernet. Men ved denne populærvitenskapelige fremstillingen kan doktorandens pedagogiske evner godt vurderes.

Alle fakulteter har beholdt forelesningen over oppgitt emne som kandidaten får ti arbeidsdager på. Bare i Norges tekniskenaturvitenskapelige universitets forskrift om prøveforelesningen er det eksplisitt

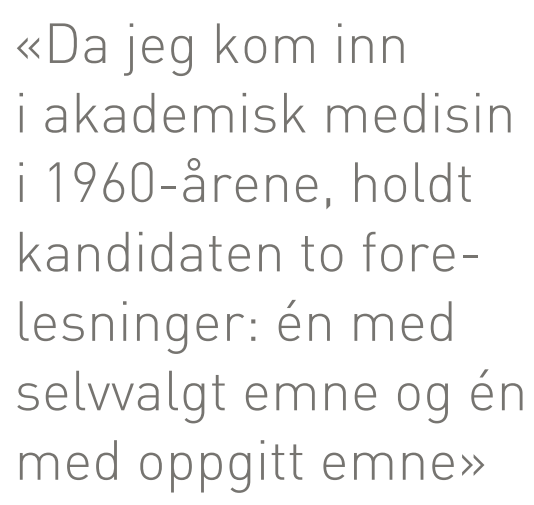

nevnt noe om valg av tema. Ved de andre fakultetene er dette opp til komiteen. Uten formelle vedtak eller faglige, nasjonale diskusjoner har det nå dessverre utviklet seg en praksis med at bedømmelseskomiteene 
velger tema som ligger tett opptil avhandlingens tema, noe tilfeldige eksempler fra nyere disputaser viser (ramme 1).

Trenden er den samme ved psykiatriske og samfunnsmedisinske disputaser. Hvorfor er det blitt slik? Jeg ser tre muligheter. Den første er at bedømmelseskomiteene undervurderer doktorandenes evne til å orientere seg i den faglige bredden. Dette er i så fall feil. Den andre muligheten er at fagområdene og subspesialiseringen er kommet så langt at heller ikke en fremtidig universitetslærer kan forutsettes å forelese utover sitt forskningsområde. Dette er ikke akseptabelt for fakultetene. I alle undervisningsfag må universitetslærerne kunne undervise bredt. Den tredje muligheten er at praksis endres på en ureflektert måte. Den feilen som ble gjort med å velge et altfor snevert valg av tema av noen bedømmelseskomiteer, ble reprodusert av de neste komiteene og av doktorandene når de selv kommer i komiteer.

Det er viktig at alle fakulteter nå tar eksplisitt stilling til hva som skal kjennetegne det oppgitte emnet for prøveforelesningen. Man bør etablere en felles praksis hvor det godt begrunnede kravet om bredde i temavalg blir tatt inn. Dette garanterer også en likeartet utfordring for doktorandene uavhengig fakultet.

\section{Per Vaglum}

p.j.w.vaglum@medisin.uio.no

Per Vaglum (f. 1938) er professor emeritus, dr.med., ved Avdeling for medisinsk atferdsvitenskap, Institutt for medisinske basalfag, Universitetet i Oslo. Han er tidligere dekanus ved Medisinsk fakultet, Universitetet i Oslo. Forfatter har fylt ut ICMJE-skjemaet og oppgir ingen interessekonflikter.

\footnotetext{
Litteratur

1. FOR 2012-01-23 nr 206: Forskrift for graden philosophiae doctor (ph.d.) ved Norges teknisk-naturvitenskapelig universitet (NTNU) § 19-1. Prøveforelesning. www.lovdata.no/cgi-wift/ldles?doc=/ sf/sf/sf-20120123-0206.html (18.6.2013).
}

Mottatt 11.6. 2013 og godkjent 18.6. 2013. Medisinsk redaktør Hanne Støre Valeur.

Publisert først på nett. 